\title{
小児呼吸器セミナー抄録
}

\section{基礎講 座}

\section{2 。気管支喘息の呼吸機能：主として ピークフローの測定について \\ 加野 草平 \\ (国立療食所南福岡病院小児科)}

\section{はじめに}

近年，各国から気管支喘息の治療・管理に関 するガイドラインが発表され, Peak expiratory flow (PEF) をもちいた治療・管理が積極的 に取り入れられている。昨年, 発表された喘息 管理の国際指針 (Grobal strategy for asthma management and prevention）においても同様 であるが，各種肺機能検査の中の 1 つの指標で あるPEFの意味について理解する必要があ る。本セミナーでは, PEF の評価に関しての注 意点, また, 臨床上モニターしていく際のメリ ットなどについて概説する。

\section{PEF の肺機能上の意義（ $\dot{\mathrm{V}}-\mathrm{V}$ curve から）}

$\dot{\mathrm{V}}-\mathrm{V}$ curve は, 努力呼出させた場合に, 縦軸 に流量 (flow), 横軸に volume をとり, 肺気量 別の呼気流量が得られる様に考案された検査で ある(図 1-a)。最大努力 $\dot{V}-V$ curve では通常最 大吸気压まで息を吸わせてから最大呼気努力で 残気量位まで呼出させる。ある肺気量以下では, 呼気努力を増加しても flow が増加しなくなる という現象, すなわち, effort-independent な現 象が認められ,この時の流量を $\dot{V} \max$ と呼ぶ。 肺気量別でみると，低肺気量位ほど少ない努力 で $\dot{V} \max$ が得られ，また逆に，肺気量位が高く なるほど $\dot{V} \max$ を得るために多くの努力を必 要とする (図 1-a)。ここで effort-independent という意味は努力を必要としないという意味で はない点に注意する必要がある。effort- independent segment については，健康成人で は75\%肺気量位までと考えられているが，小照 での詳細な検討はない。通常, PEF は75\%以上 の高肺気晕位 (effort-dependent segment) に認 められ，その值は患者の努力によって大きく左 右される指標である (四 1-b)。従って, 個々の 患者に常に最大呼出努力をさせることが重要で ある。その際, 呼出する際の肺気量によって PEF は変化するので, 常に最大吸気位から呼出 させることも重要である。PEF は努力依存性で あるので, 肺胞内圧（PA）と比例関係にある。 $\mathrm{PA}=\mathrm{REF} \times \mathrm{Raw}$ （Raw：気道抵抗）で表され る。気道抵抗值には, 上気道, 中枢気道の寄与 が大きく，気流の駆動圧の約 $80 \%$ が口から亜区 域気管支レベル位の間で使われるため, PEF は 亜区域気管支より中枢の太い気管支の狭窄を反 映すると考えられている。上記の式から気道抵 抗と PEFとの関係は双曲線関係にあり, 気道 抵抗が小さいときのPEF は大きいが，気道抵 抗のわずかな変化による PEF の変動は大きく 気道抵抗を鋭敏に表す。しかし，気道抵抗が高 い場合は, PEF は低值となり, 気道抵抗の変動 にともなうPEF の変動も小さくなる（図 2 )。 従って, 非発作時にPEF がほぼ正常に保たれ ているような喘息患者での発作の検出には優れ ていると考えられている。その他, spitting の手 技や煩を膨らませて口腔内に貯めた空気を吐き 出させる方法を呼出時に行うと, air decompression により $\dot{\mathrm{V}}-\mathrm{V}$ curve上 PEF に一致し て over shootが認められ, PEF が高くなるの 


\section{Expir. flow (1/s)}

Expir. flow (1/s)

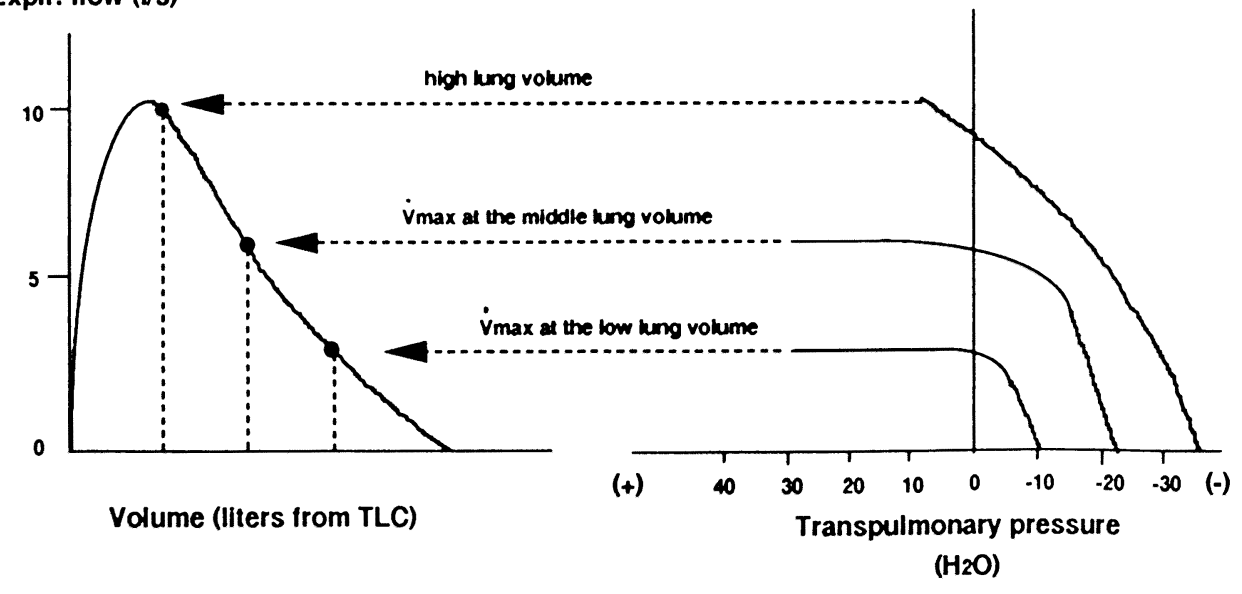

図 1-a flow-volume curve $と$ isovolume pressure-flow curve

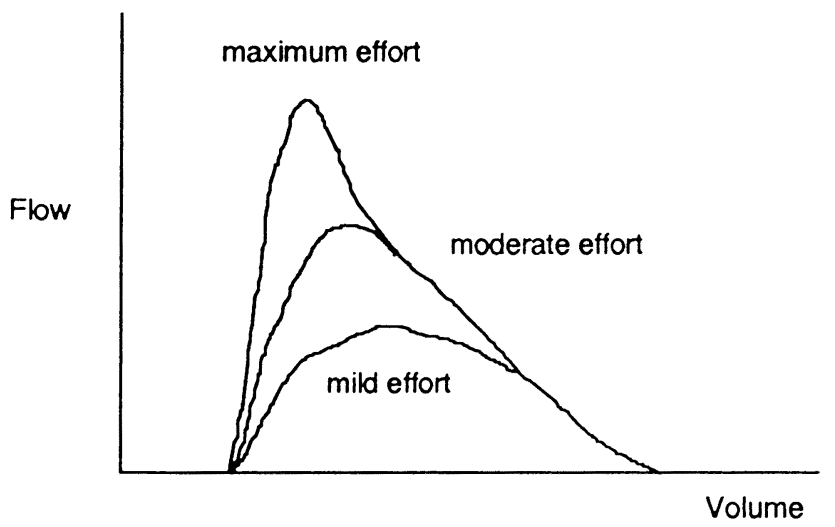

図 1-b 最大吸気位から珙なった努力で呼出させた場合の $\dot{\mathrm{V}}-\mathrm{V}$ curve

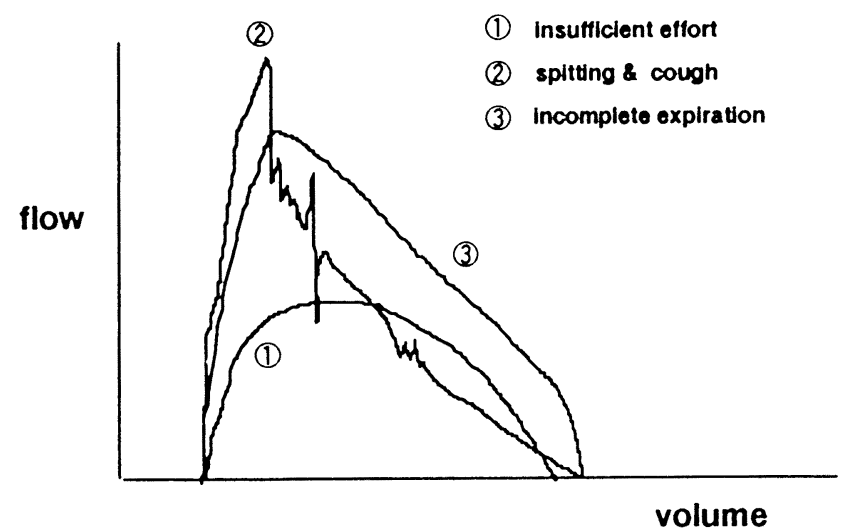

図 1-c 種々の呼出パターンの違いによるPEFの違い 


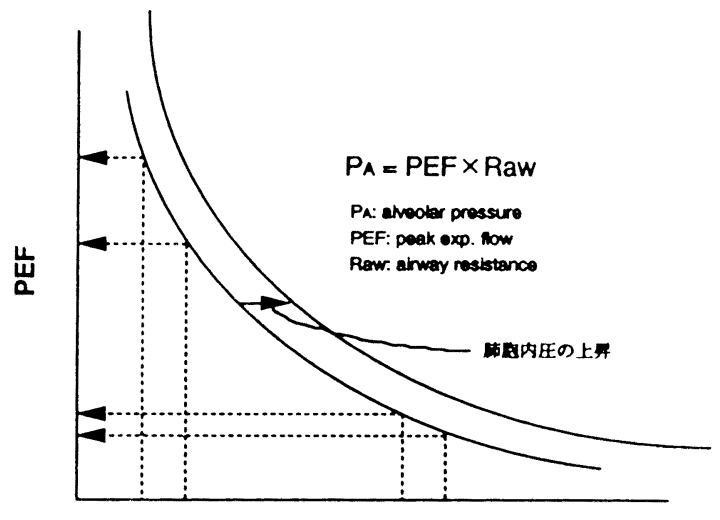

匃道抵抗 (Raw)

図 2 気道抵抗とピークフローとの関係

で注意が必要である（図 1-c）。

\section{気管支喘息児における非発作時の $\dot{\mathbf{V}}-\mathbf{V}$ curve}

図 3 に健康児および非発作時の気管支喘息時 の重症度別の各換気パラメーターを示す。非発 作時には，末梢気道のパラメーターである MMF， $\dot{\mathrm{V}}_{50}, \dot{\mathrm{V}}_{25}$ は重症度に沿って低下してい るが，PEFでは重症度別の違いは認められな い。従って, 非発作時にはPEF のみで重症度を 判定することは困難である。図 4 は当院小児科 で経験した喘息死症例，大発作の既往のある重 症群，入院歴もほとんどない軽症群の非発作時 の肺機能を示す。喘息死群，大発作時の $\dot{V}_{50}$ は 軽症群と比して有意に低下していたが, PEFで はほとんど臨床時に問題となるような差は認め られていない。以上のことから非発作時に肺機 能から臨床的重症度を推定することはPEFで は困難で，他の末梢気道のパラメーターで評価 する必要がある。

\section{PEF の努力依存性}

図 5 は PEF の努力の影響を 1 秒量 $\left(\mathrm{FEV}_{1.0}\right)$ と比べた成績で， 6 〜 15歳の気管支喘息児17名 に，異なった努力で計 6 回非発作時に最大吸気 位から呼出させた場合の PEF と $\mathrm{FEV}_{1.0}$ の変 動の違いを検討したものである。PEF は努力の 影響が大きく，1秒量ではその影響がかなり少 ないことが分かる。従って, PEF の変動を見る
場合，努力による䛊差が大きいことを考虑し， 数回吹かせ，その最高值を採用することも必要 である。また, 患者や保護者にこの呼出努力の 測定值に及ぼす影響を認識させる必要がある。

\section{発作時のPEF の変化}

図 6 にアセチルコリン（Ach）吸入試験中の) PEF の変化を示す。対象は 6 14歳の喘息児 で, Ach 吸入後のPEF と $\mathrm{FEV}_{1.0}$ の変化を同時 に示す。小学生, 中学生共に, PEF のばらつき の大きな症例は数名存在するが最終的には $\mathrm{FEV}_{1.0}$ と同程度の低下が認められており, 発作 が起こった場合には, PEFでも十分に発作の程 度を把握できると考えられる。

当院小児外来に気管支発作で受診した $7 \sim 17$ 歳の喘息患者 94 名の吸入前後での PEF, $\mathrm{FEV}_{1.0}$ の変化を入院の有無別に図 7-aに示す。\%值は 予測値（西間の予測式）からの\%で表されてい る。延べ発作回数は300回で, 入院に至った群で は入院に至らなかった群と比べて有意に\% $\mathrm{PEF}, \% \mathrm{FEV}_{1.0}$ は低く, 入院群では\%PEF は平 均で吸入前 $33 \%$ から吸入後 $51 \%$ であった。いっ たん帰宅したが 24 時間以内に入院になった群に ついては，24時間以内に入院に至らなかった群 と比べても吸入前後の值に有意差を認めず，吸 入前後の\% PEF で 24 時間以内の入院を予測す ることは困難であった。しかし，吸入後の\% $\mathrm{PEF}$ が $80 \%$ 以上ある場合は自宅で様子をみる 

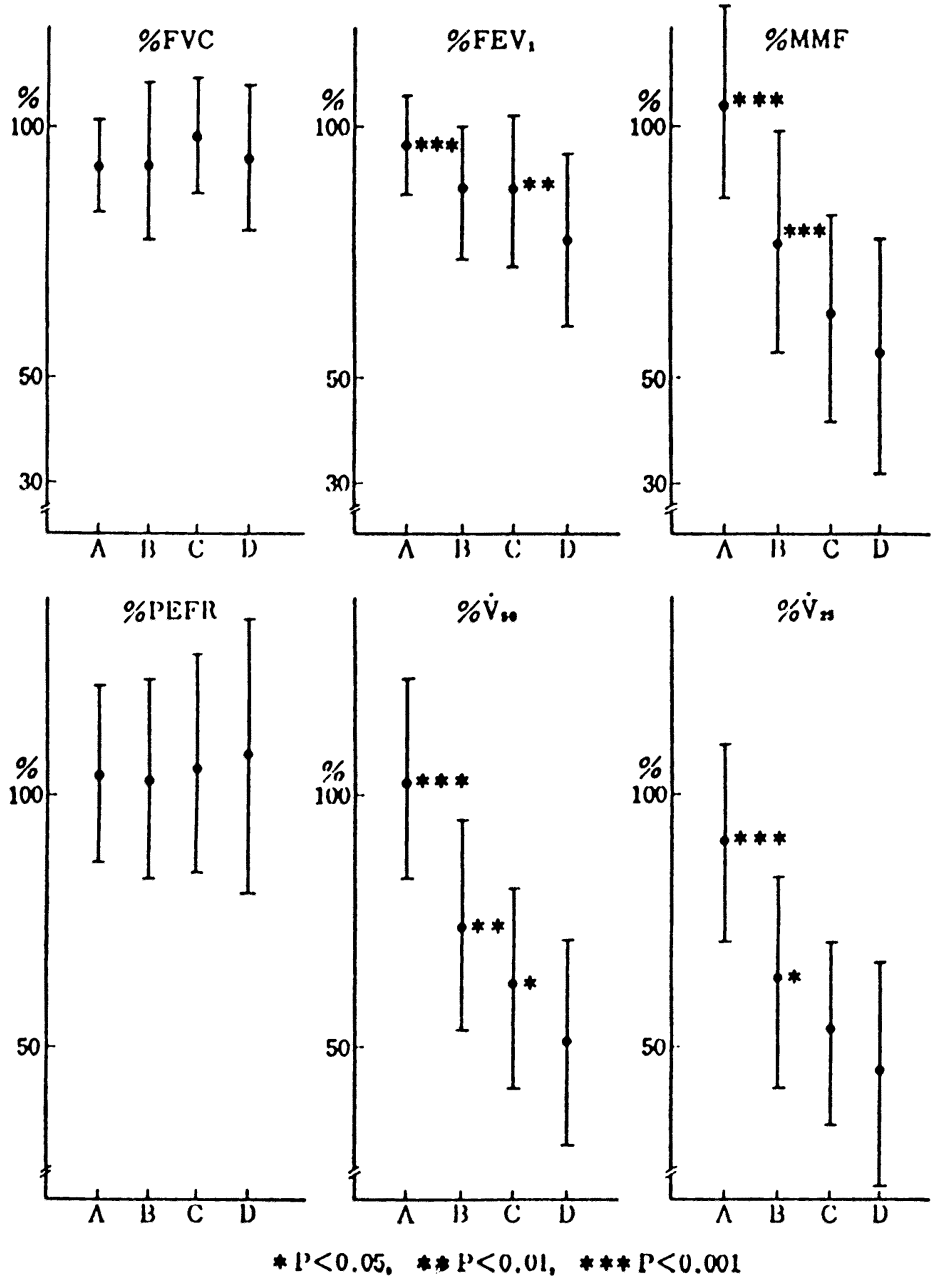

図 3 健康児および非発作時の気管支喘息児の換気機能

$\mathrm{A}$ ：健康児49例， B：軽症児50例， C：中等症児51例,

D：重症児38例, mean $\pm S D$

ことも可能で，一方，50\%以下の場合は病院で の継続した治療が必要であると考えられる。吸 入後の各群の\%PEFの分布を図 7-b に示す。諸 外国のガイドラインによれば，1時間に数回気 管支拡張剂の吸入を行って吸入後の\%PEF が 60〜80\%以下の場合，家庭・外来での経口ステ ロイドの適応となっている(図 8 )。今回の外来 発作での治療内容と多少のずれはあるが, 単純 にその適応を当てはめると, 吸入後の\%PEF が 80\%以下であった194回, 65\%の発作エピソード
に，小児科でも発作時に短期的ではあるが経口 ステロイドを処方することになり，その是非に ついて今後慎重に検討する必要がある。

\section{ピークフロー（PEF）による小児気管支喘息}

\section{の慢性期の管理}

当院に施設入院療法中の気管支喘息患者 32 名 (年齢 $6 \sim 15$ 歳)で, 頻回の気管支拡張剤の吸入 とアミノフィリンの持続点滴, あるいはステロ イドの静注を必要とする発作 (延べ回数，40回) 


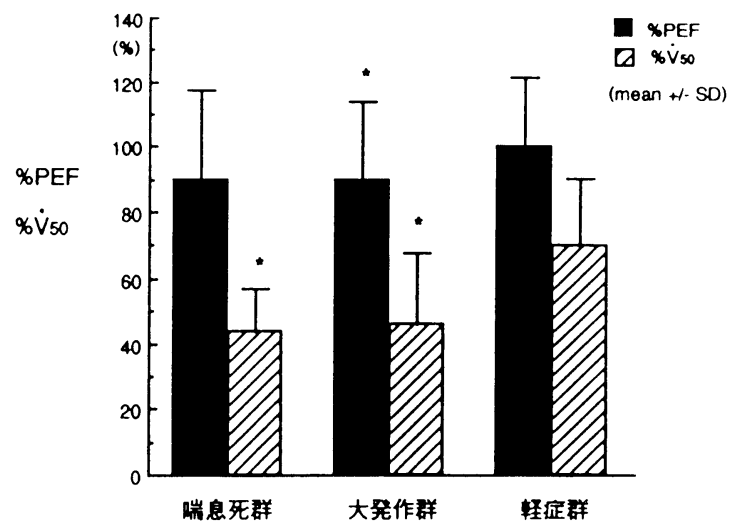

図4 各群における\% PEF と\% $\dot{\mathrm{V}}_{50}$ (flow-volume curve) ${ }^{*} \mathrm{P}<0.05$ 軽症群と0)比較
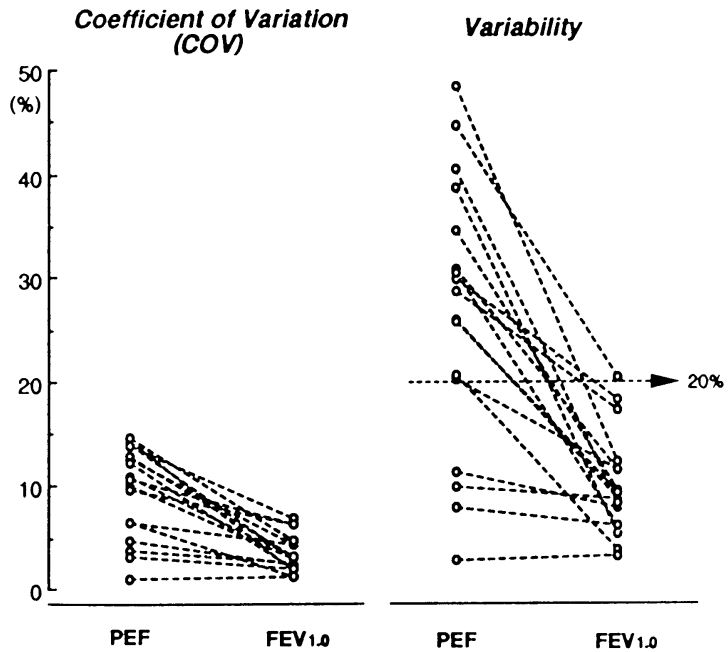

$\operatorname{COV}(\%)=($ standard deviation mean value $) \times 100$

Variability $(\%)$ - (maximum value- minimum value) / mean value $\times 100$

図 5 PEF と $\mathrm{FEV}_{1,0}$ の呼出努力による影響

(計 6 回異なった努力で呼出させた埸合の変動の差)

を起こす前 4 週間の PEF の変化を検討した。 発作前 1 週間は前 $2 \sim 3$ 週間に比べて, \% $\mathrm{PEF}, \% \mathrm{FEV}_{1.0}$ は有意に低く，また，それぞれ の日内変動は高く, 点滴を要する発作が近づく につれ，肺機能が徐々に悪化し，変動も大きく なっていることが示されている（図 9-a）。図 9 -b は発作前 2 週間と施設入院中最も安定して いた 2 週間を同様のパラメーターで比較したも のであるが，安定していた 2 週間は，発作前に 比べて \% $\mathrm{PEF}, \% \mathrm{FEV}_{1.0}$ は有意に高く, 一方, それぞれの変動係数は有意に低く, PEF の変動 係数の平均值は $20 \%$ 以ドであった。点滴を要す 
6 - 11 years-old
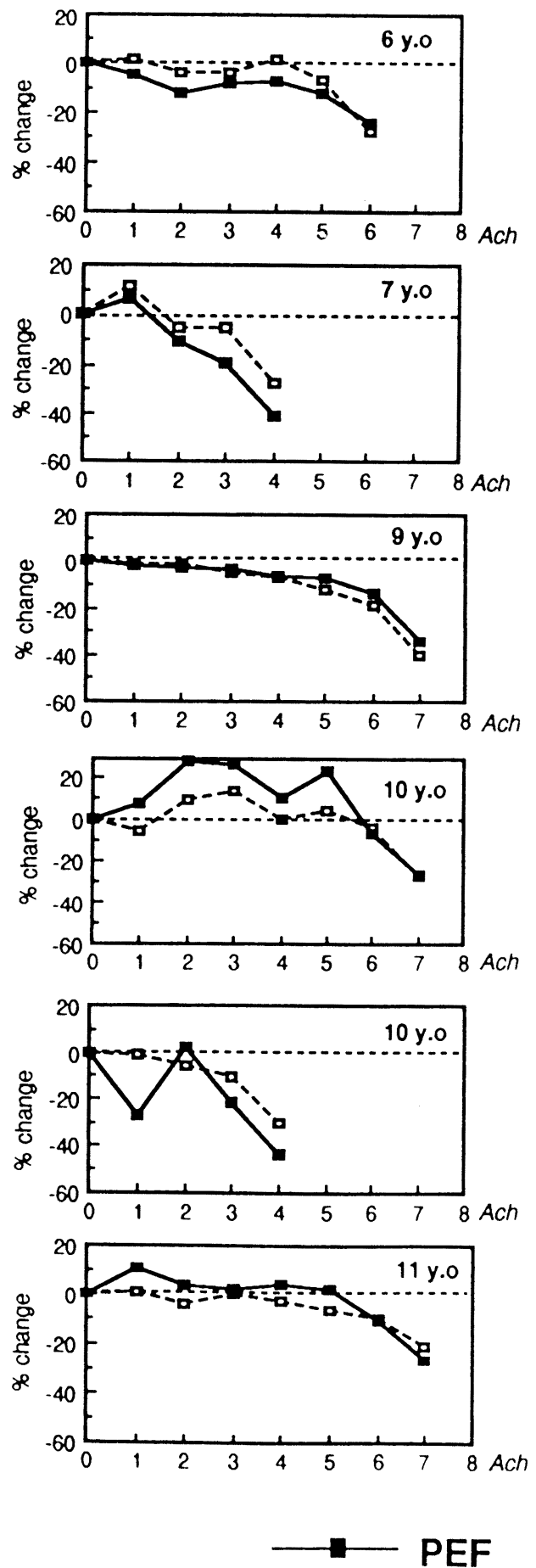

$12-14$ years-old
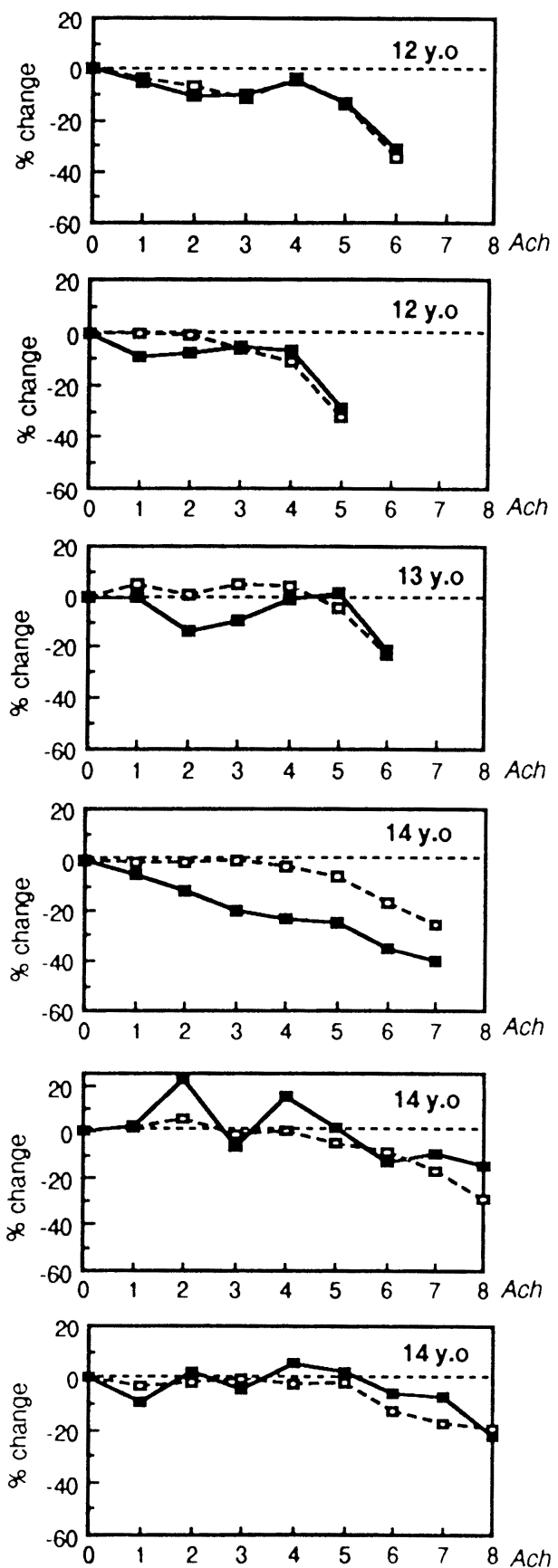

FEV 1.0

図 6 アセチルコリン吸入試験中の $\mathrm{PEF}$ および $\mathrm{FEV}_{1.0}$ の推移 
日本小児呼吸器疾患学会雑誌，7 (2), 1996

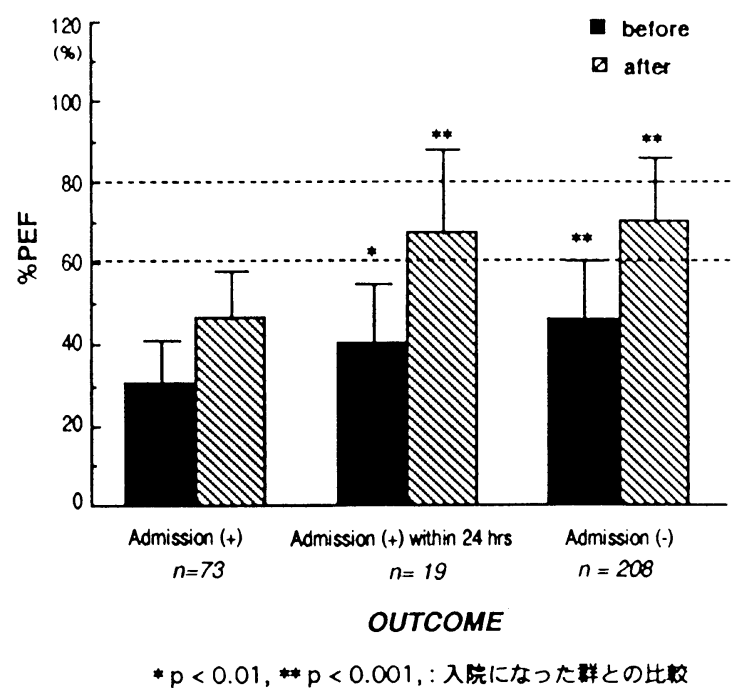

図 7-a 喘息発作で来院した患児の吸入前後の\%PEF の変化

$194 / 300(65 \%): \%$ PEF $<80 \%$

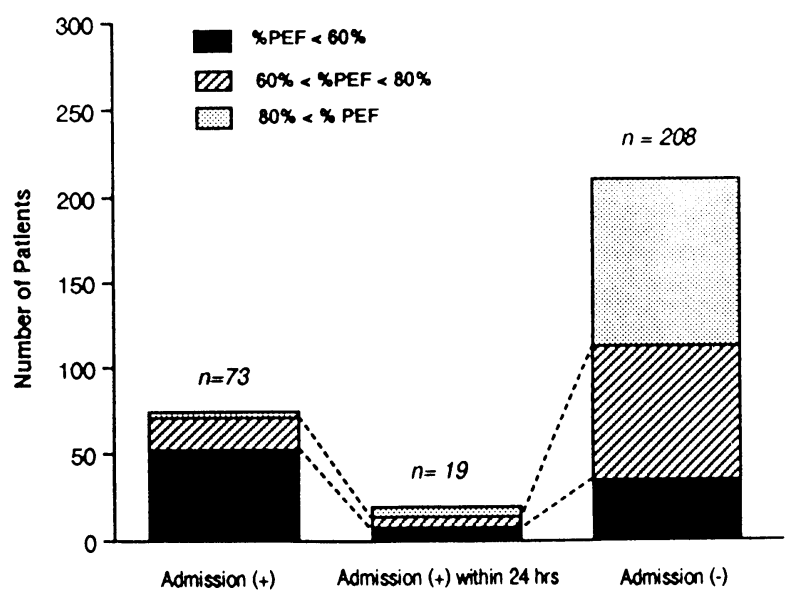

図 7-b 喘息発作で来院した患児の吸入後の\%PEF の分布

る発作以前は発作がなく, 突然点滴を要する発 作に至った群と発作が徐々におこって点滴が必 要になった群に分けて検討した結果, 突然点滴 を要する発作に至った群では，その前 4 週間の 間に\% $\mathrm{PEF}, \% \mathrm{FEV}_{1.0}$ やそれぞれの日内変動率 に有意な変化は認められなかった(図10-a, b)。 したがって点滴を要する発作前 4 週間という比
較的短期間内では，突然点滴に至るような発作 を肺機能から予測していくのは困難であると考 えられた。次に, 突然点滴を必要とする発作を おこした群について，その発作前 2 週間と施設 入院中最も安定していた 2 週間とを比較した結 果を四11に示す。 $\% \mathrm{PEF}, \% \mathrm{FEV}_{1.0}$ には有意な 差は認められなかったが, 日内変動率でみると, 
重症度の把握（PEF, 症状）

切期治療

短時間作用型吸入 $\beta 2$ 刺激薬

( 1 時間に 3 回まで)

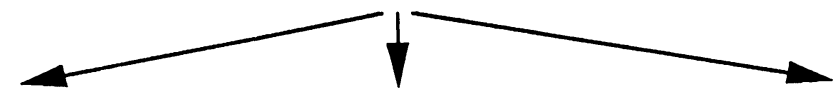

好果あり

効果不十分

奻果なし

軽度発作（PEF > 80\%）

陮薬に対する反応

が4時間持繶

$\beta 2$ 刺激薬を3-4時間毎 追加可

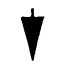

臨床医の診察
中等度発作 $(60 \%<\mathrm{PEF}<80 \%)$

程ロステロイド追加

$\beta 2$ 刺激薬を釉繶

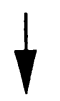

その日のうちに臨床医の指示
高度発作 $(\mathrm{PEF}<50 \%)$

経ロステロイド追加

直ちに $\beta 2$ 刺激薬を反復

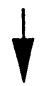

直ちに救急外来へ

（救急車の利用を検討）

図 8 急性発作時0家庭に抢ける治療

(Grobal Strategy for Asthma Management and Preventionによる)
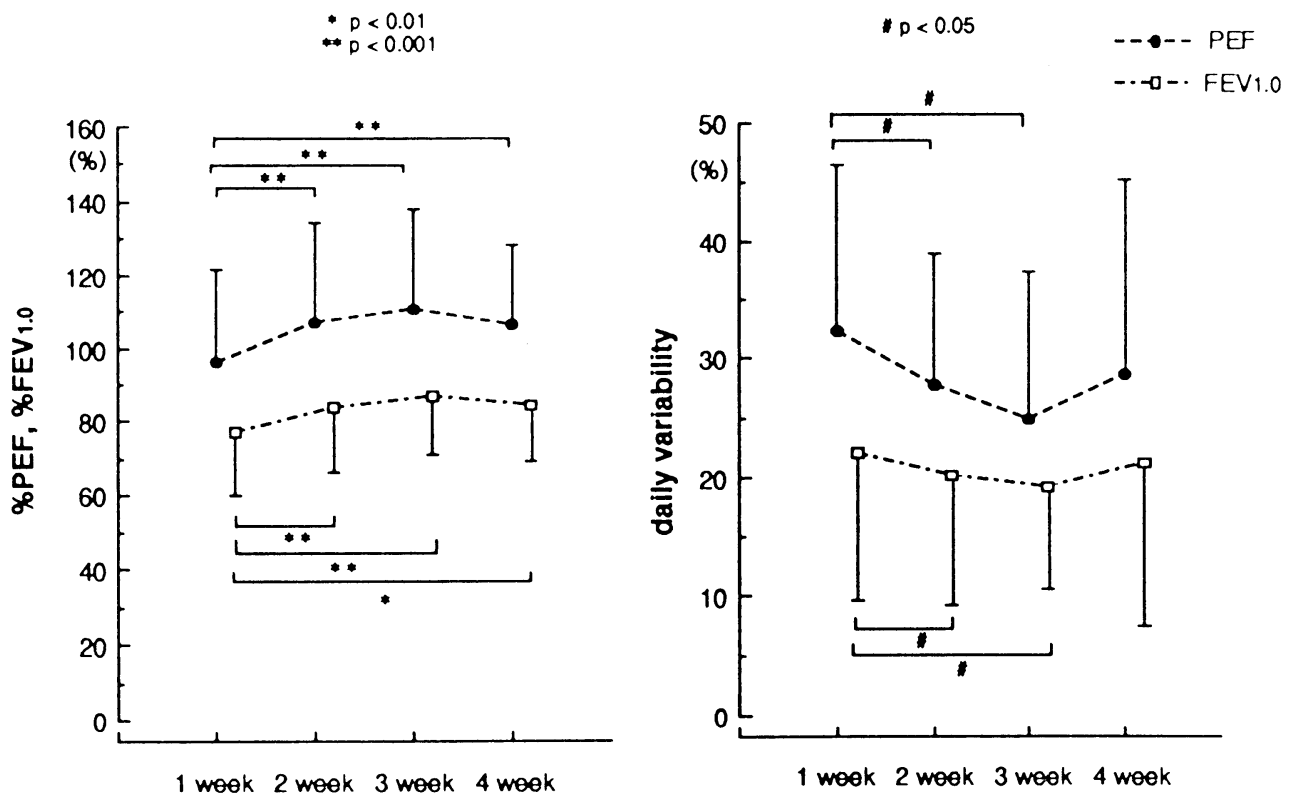

図 9-a 点滴を要する発作前の肺機能の変化 
日本小児呼吸器疾患学会雑誌，7 (2)，1996
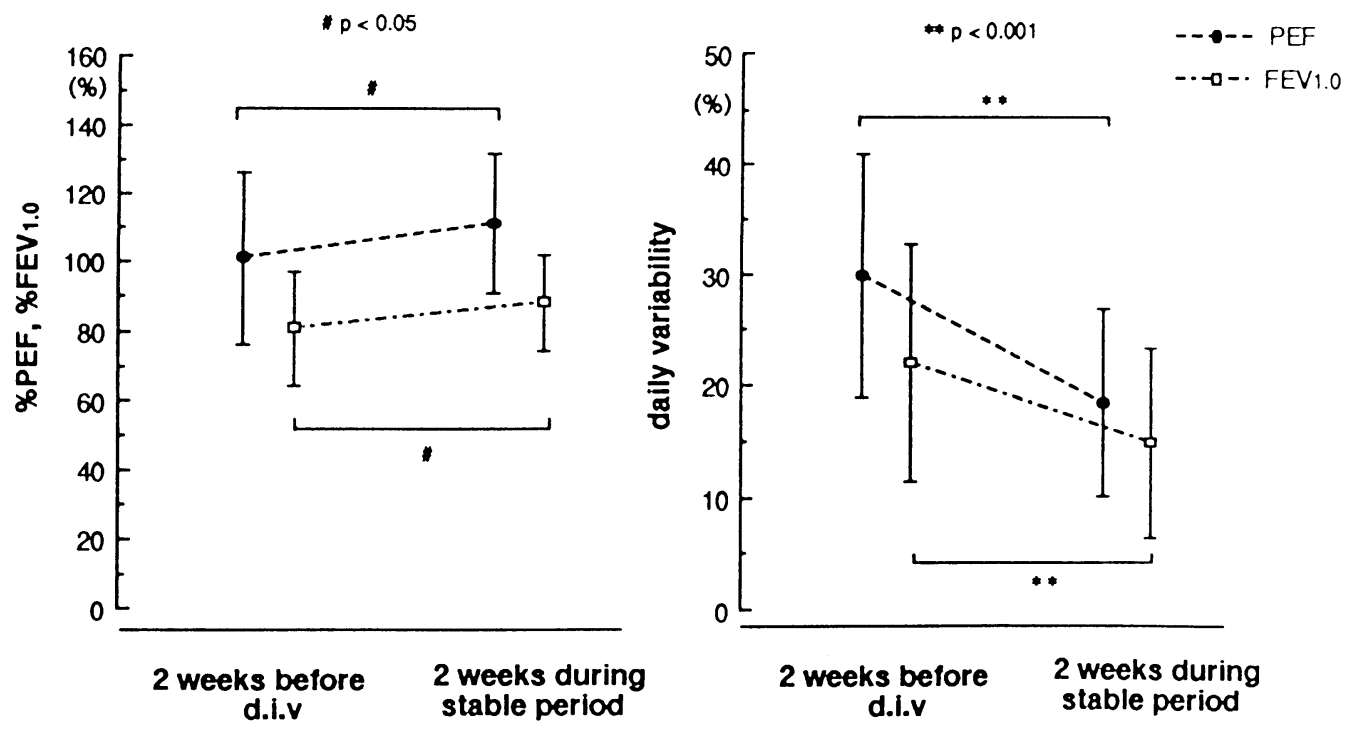

図 9-b 点滴を要する発作前 2 週間と安定していた 2 週間の肺機能の比較

\section{Change in \%PEF}

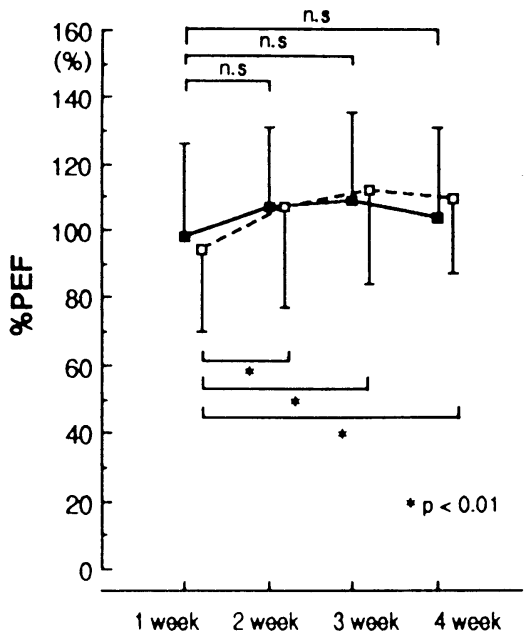

Change in \%FEV 1.0

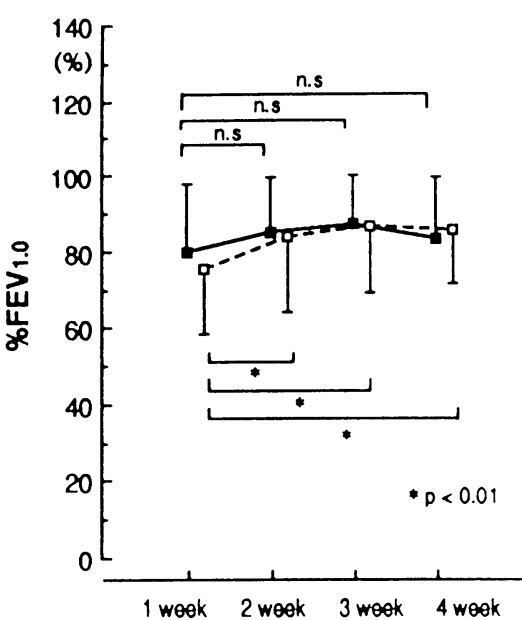

$\longrightarrow$ group with no attack for 1 week before d.I.v. ( $N=16)$

$--\infty$ group with attacks for 1 week before d.l.v. $(N=24)$

図10-a 点滴を要する発作前 4 週間の肺機能の変化

(突然発作に至った群と徐々に悪化した群の比較) 
Averaged dally varlability in PEF

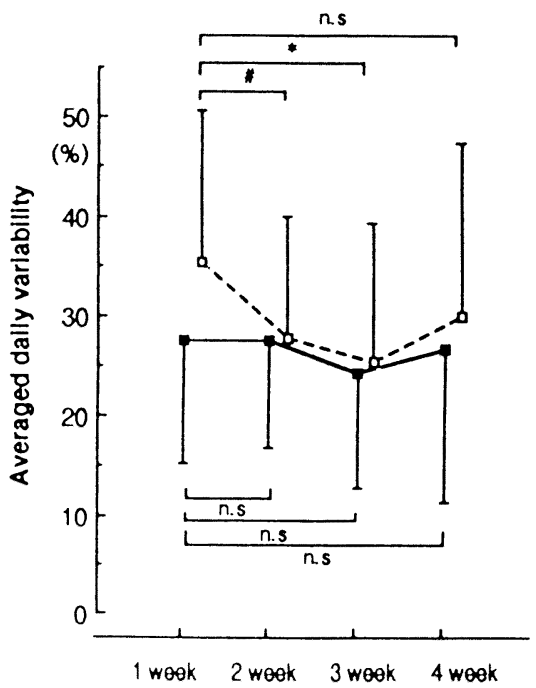

Averaged daily variability In FEV 1.0

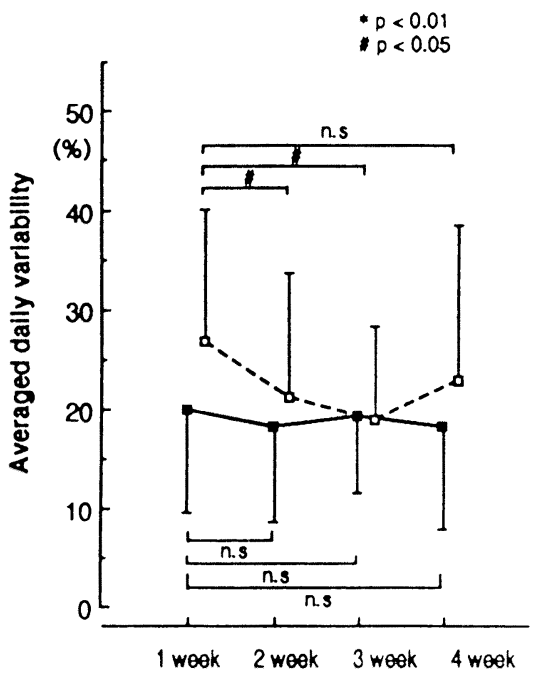

$\longrightarrow$ group with no attack for 1 week before d.I.v. $(N=16)$

- - . group with attacks for 1 week before d.I.v. $(N=24)$

図 10-b 点湳を要する発作前 4 週間の肺機能の日内変動の変化 (突然発作に至った群と徐々に悪化した群の比較)

Group with no attack for 1 week before d.i.v. $(N=16)$

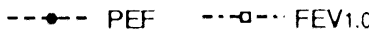
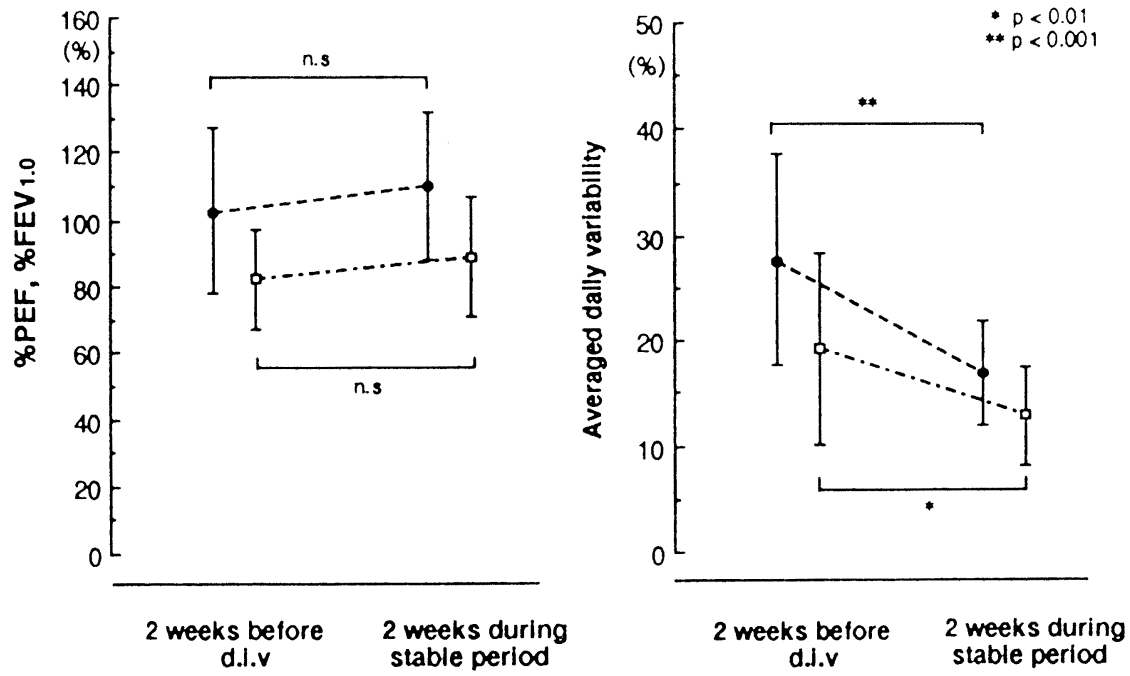

図11 突然点滴を必要とする発作に至った群に打ける肺機能 （点瀜前 2 週間と安定していた 2 週間との比較） 
日本小児呼吸器疾患学会雑誌，7 (2), 1996
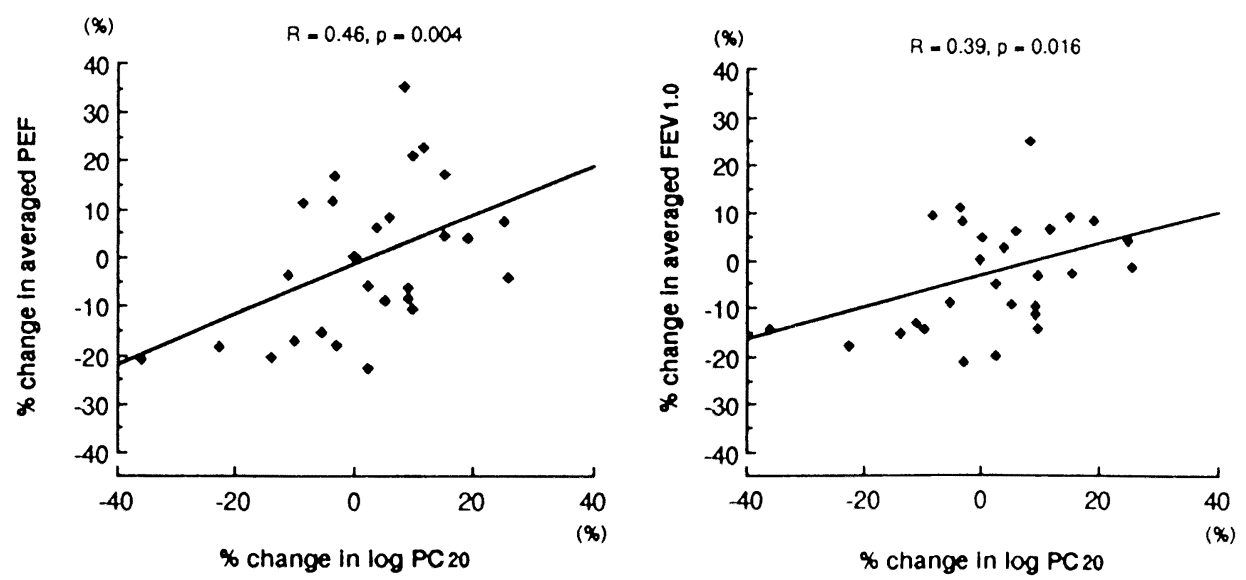

* Averaged PEF and FEV 1.0 were obtained from measurements (2 times/day) for 1 week before Ach inhalation test

図12-a $\mathrm{PC}_{20}$ の変化率と\% $\mathrm{PEF}, \% \mathrm{FEV}_{1.0}$ の変化率との関係
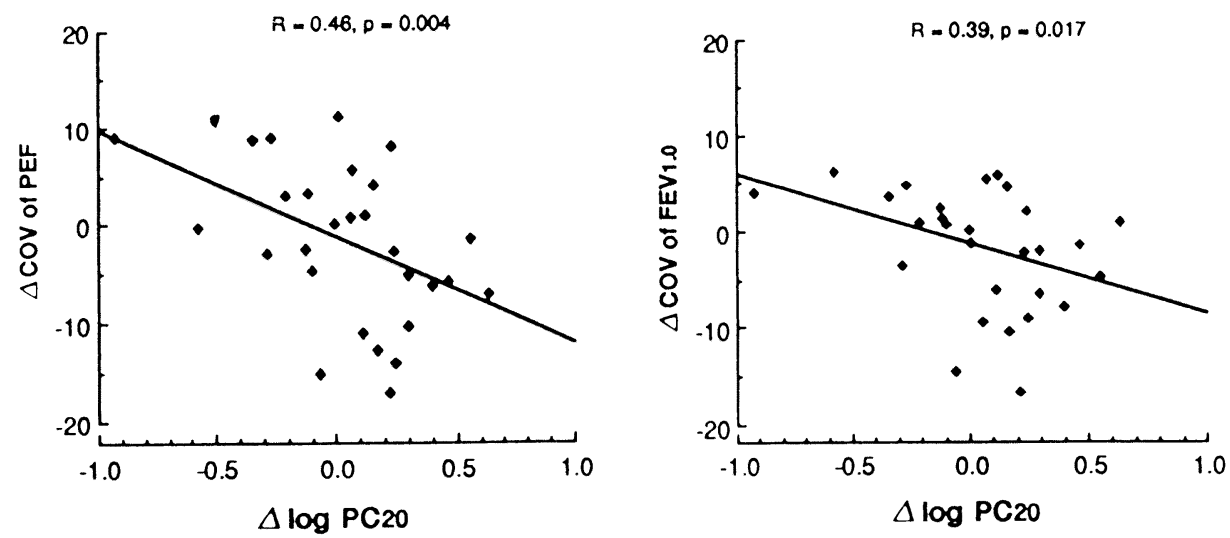

* COV of PEF and FEV 1.0 were obtained from measurements (2 times/day) for 1 wook before Ach inhalation test

図12-b $\mathrm{PC}_{20}$ の変化率と\% $\mathrm{PEF}, \% \mathrm{FEV}_{1.0}$ の変動係数の変化との関係

安定期の 2 週間の方が有意に低く，喘息日誌上 一見安定しているように見えても，その症例の 最も安定した時期の日内変動率と比べて悪化が 認められれば，発作に至る可能性が高いと考え られる。

\section{PEF の日内変動と気道過敏性との関係}

$8 \sim 14$ 歳の気管支喘息児10名に 1 週間以上の 間隔をあけて 2 回以上の Ach による気道過敏 性試験を行い, 検查前 1 週間の PEF, $\mathrm{FEV}_{1.0}$ の 変化と気道過敏性 $\mathrm{PC}_{20}$ の変化との関係を検討 した。 $\mathrm{PEF}, \mathrm{FEV}_{1.0}$ の変化率と $\mathrm{PC}_{20}$ の変化率 


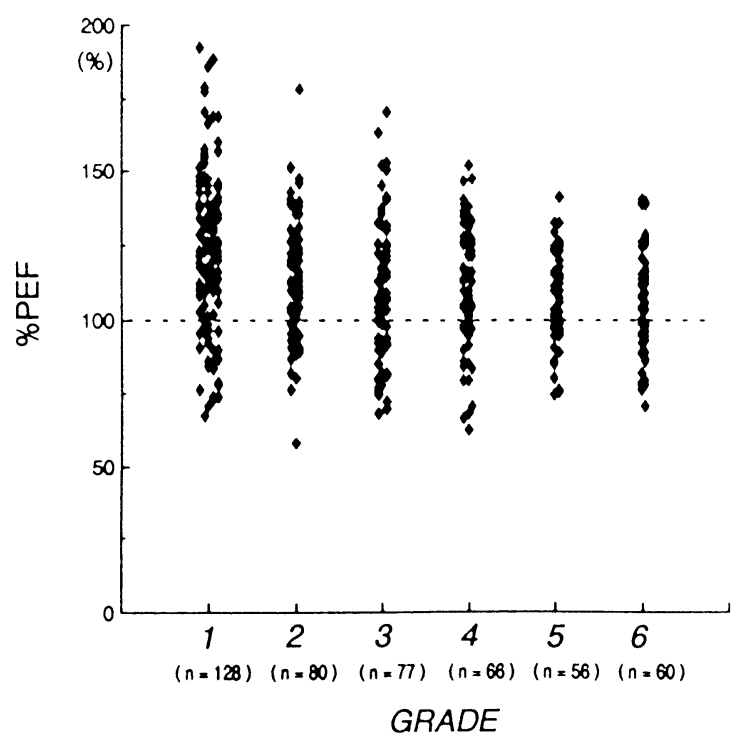

図13喘息照童467名の学年別の\%PEF の分布（西間の予測式を使用）

との関係では, PEF, $\mathrm{FEV}_{1.0}$ の変化率と $\mathrm{PC}_{20}$ の変化率との間には有意な正の相関が認めら れ, PEF, $\mathrm{FEV}_{1.0}$ の 1 週間の変動係数の変化と $\mathrm{PC}_{20}$ の変化との関係では負の相関関係を認め ており，変動が大きくなるにつれ， $\mathrm{PC}_{20}$ は低下 (気道過敏性が方進)していた（図13-a，b）。

以上の様に PEFを長期的に monitoring す ることによって, 点滴を要する発作への移行を 予測することは可能であると考えられ，喘息日 誌上の主観的判断にマスクされた肺機能の変化 を知ることは臨床上有用である。

\section{\%PEF の評価について (personal best PEF or predicted value?)}

図13に小学生の喘息児467名の学年別の予測 值 (西間の予測式) から計算した\%PEF を示す。 小学校低学年になるにつれ, \%PEF のばらつき がかなり大きくなり小学 1 年生では\%PEF が $200 \%$ 近くにのぼる例も存在する。従って, 小学
校低学年では予測值から求めた\% $\mathrm{PEF}$ で発作 の状態を判断した場合，注意が必要であり個人 の best PEF を用いた方がより有用と考えられ る。しかし，個人の best PEFをどの様にして求 めるかの問題は残り，成人領域では $1 \sim 2$ 週間 経口ステロイドを服用させ個人の personal best PEF を求めることが検討されているが, 小 児では副作用の面を考慮すれば困難である。従 って，1〜2 力月位の観察期間をおいてその間 の PEF を参考に臨床症状や予测值を参考にし て，その時点での best PEF を設けることが現 時点では適切ではないかと考えられる。また， 各年齢別の PEF の予測值にどの予測式が適切 であるかも不明で，さらに，スパイロメーター で測定した PEF と簡易型ピークフローメータ 一で測定したPEF との間の䛊差や，機種間の 測定值の違いなども報告されて抢り，測定にあ たつてはそれらの因子についても考慮する必要 がある。 